\title{
Quantitative Mass Spectrometry Imaging to Study Drug Distribution in the Intestine Following Oral Dosing
}

Citation for published version (APA):

Huizing, L. R. S., McDuffie, J., Cuyckens, F., van Heerden, M., Koudriakova, T., Heeren, R. M. A., \& Vreeken, R. J. (2021). Quantitative Mass Spectrometry Imaging to Study Drug Distribution in the Intestine Following Oral Dosing. Analytical Chemistry, 93(4), 2144-2151.

https://doi.org/10.1021/acs.analchem.0c03956

Document status and date:

Published: 02/02/2021

DOI:

10.1021/acs.analchem.0c03956

Document Version:

Publisher's PDF, also known as Version of record

Document license:

Taverne

Please check the document version of this publication:

- A submitted manuscript is the version of the article upon submission and before peer-review. There can be important differences between the submitted version and the official published version of record.

People interested in the research are advised to contact the author for the final version of the publication, or visit the DOI to the publisher's website.

- The final author version and the galley proof are versions of the publication after peer review.

- The final published version features the final layout of the paper including the volume, issue and page numbers.

Link to publication

\footnotetext{
General rights rights.

- You may freely distribute the URL identifying the publication in the public portal. please follow below link for the End User Agreement:

www.umlib.nl/taverne-license

Take down policy

If you believe that this document breaches copyright please contact us at:

repository@maastrichtuniversity.nl

providing details and we will investigate your claim.
}

Copyright and moral rights for the publications made accessible in the public portal are retained by the authors and/or other copyright owners and it is a condition of accessing publications that users recognise and abide by the legal requirements associated with these

- Users may download and print one copy of any publication from the public portal for the purpose of private study or research.

- You may not further distribute the material or use it for any profit-making activity or commercial gain

If the publication is distributed under the terms of Article $25 \mathrm{fa}$ of the Dutch Copyright Act, indicated by the "Taverne" license above, 


\title{
Quantitative Mass Spectrometry Imaging to Study Drug Distribution in the Intestine Following Oral Dosing
}

\author{
Lennart R. S. Huizing, James McDuffie, Filip Cuyckens, Marjolein van Heerden, Tatiana Koudriakova, \\ Ron M. A. Heeren, and Rob J. Vreeken*
}

Cite This: Anal. Chem. 2021, 93, 2144-2151

Read Online

ACCESS | Llll Metrics \& More | 国 Article Recommendations ｜９） Supporting Information

ABSTRACT: Local delivery to the lower gut to treat diseases of the colon has become a topic of special attention. Tissue exposure of locally acting agents is not represented by plasma concentrations. Therefore, reliable methods to measure tissue uptake at the primary site of action (e.g., epithelial layer or lamina propria) are vital. This work investigates the suitability of mass spectrometry imaging (MSI) in quantitatively visualizing intestinal transmural drug distribution. Tofacitinib (Tofa), a drug approved for the treatment of several autoimmune diseases, including ulcerative colitis, was selected as a tool compound for feasibility studies. Oneand 7-h postdose sections of the ileum, proximal- and distal-colon from rats that received an oral solution of Tofa were subjected to

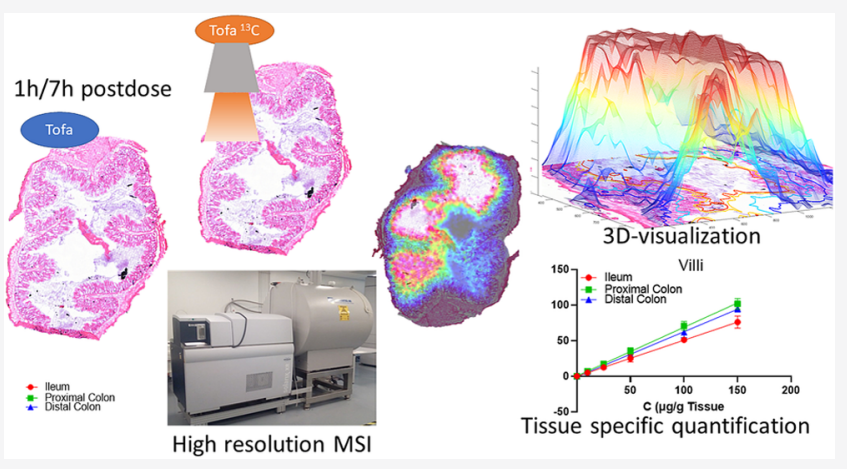
matrix-assisted laser desorption ionization (MALDI)-MSI. A dilution series of individual concentrations sprayed over an entire tissue section allowed for tissue type-specific quantitation. At $1 \mathrm{~h}$ (systemic $T_{\max }$ ), the signal was highest in the ileum, whereas at $7 \mathrm{~h}$, the signal was highest in the colon, when the unabsorbed fraction of the compound reached the colon. A combination of three-dimensional (3D) intensity plots and hematoxylin and eosin $(H \& E)$ stains showed a visually observable gradual decrease in Tofa concentration from the lumen toward the muscular layer of the proximal colon. The high luminal concentration of Tofa indicated that flushing of the intestines with saline does not result in complete removal of the drug material from the lumen. This could cause an overestimation of drug concentration in gut tissue homogenates by conventional liquid chromatography-mass spectrometry (LC-MS) methods. This study demonstrates the utility of MSI to differentiate between the lumen and intestinal wall layers and enables proper interpretation of tissue distribution data.

\section{INTRODUCTION}

An important part in the development of new drugs is the understanding of their absorption profiles along the gastrointestinal tract (GI tract) as well as the distribution to the site of action. ${ }^{1,2}$ In particular, for GI restricted drugs, an accurate representation of tissue exposure is critical. Local delivery to the distal GI tract (the ileum and the colon) to treat intestinal diseases such as inflammatory bowel disease (IBD) or colon cancer has been of special attention in recent years. ${ }^{3-5}$ Tissue exposure of locally acting drugs is generally not represented by systemic plasma concentrations. An accurate method to measure drug distribution at the primary site of action such as the intestinal epithelial layer and lamina propria within both the small intestine and the colon tissue is therefore of great value. ${ }^{1,2}$ Recently, these authors described a model to study early absorption profiles along the crypt-villus axis along different sections of the small intestine by mass spectrometry imaging (MSI). However, profiles over longer time points and especially in the colon have not been described. This is especially relevant for the comparison of systemic (early) delivery compared to the later local delivery to the colon. In addition, a quantitative model is required to provide a more accurate description of absorption profiles and tissue exposure. ${ }^{1}$

Matrix-assisted laser desorption ionization (MALDI) MSI is increasingly used as a technique to study the distribution of drugs in tissues. ${ }^{1,6-10}$ Similar to liquid chromatography-mass spectrometry (LC-MS), MSI can detect a drug and its metabolites without the need for (radio) labeling. Yet, whereas in LC-MS experiments, the tissue must be homogenized for analysis resulting in the loss of spatial information, in an MSI experiment the spatial information of the analyzed molecules remains preserved. In addition, MSI can be combined with classic histological staining methods such as hematoxylin and eosin (H\&E) staining on either the measured section or an

Received: September 18, 2020

Accepted: January 5, 2021

Published: January 20, 2021

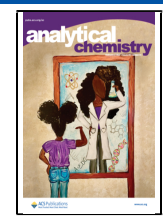


adjacent section so that the obtained molecular information can be correlated with the anatomical location. ${ }^{11}$

Despite many developments, quantification in MSI is still challenging. A key factor to account for, in order to quantify MSI results, is ion suppression..$^{7-10,12-14}$ Especially in a heterogeneous tissue like the intestine where there are not only different tissue types but also a large proportion of lumen where the analyte-to-MALDI matrix ratio is very different compared to the tissue, the ion suppression effect can vary greatly between the different areas. Therefore, more conventional methods like spotting a dilution series onto the control tissue or the mimetic tissue model where a dilution series is prepared in tissue homogenate will not provide accurate data. In addition, the accuracy and reproducibility of spotting standards are further hampered by the "coffee stain effect" resulting in an uneven distribution of standards across the spot. ${ }^{15} \mathrm{~A}$ more precise method is the use of the tissue extinction coefficient where a standard is sprayed on the tissue and the ratio between on-tissue versus off-tissue is calculated to provide the tissue-specific ion suppression effect. However, this technique assumes that the tissue extinction coefficient (TEC) per tissue type is linear to the concentration curve. ${ }^{14}$ Alternatively, one can correlate the dilution series on the tissue with a fixed concentration of the stable isotope-labeled internal standard. We propose spraying of the dilution series of drugs on the control tissue followed by spraying a fixed concentration of the stable isotope-labeled internal standard to prevent the issues that occur with spotting on the tissue. Spraying the dilution series over the tissue sections with a robotic sprayer provides an even coating on each tissue section. Furthermore, each tissue type, as well as the area without tissue, will have a similar amount of standard per unit area for each tissue type, resulting in a tissue type-specific calibration curve. With the addition of the isotope-labeled internal standard, the ratio of the drug signal intensity versus the isotope-labeled standard signal intensity can be correlated with the concentration.

Tofacitinib (Tofa) was chosen as a tool drug to assess the feasibility to quantitate the distribution into the lamina propria (site of action) from both the blood and the lumen side. Tofa, a Janus-kinase inhibitor used in the treatment of rheumatoid arthritis and ulcerative colitis, is currently under investigation for other indications such as Crohn's disease. ${ }^{16-18}$ Tofa is well absorbed in the intestine with over $70 \%$ predicted passive absorption in humans based on Caco- 2 cell permeability experiments. ${ }^{16}$ Tofa is rapidly absorbed in the GI tract and reaches peak concentration in plasma after 15-30 $\mathrm{min}$ in rats and $30-60 \mathrm{~min}$ in healthy humans. ${ }^{19}$ Half-life for Tofa is approximately $0.6-2.8 \mathrm{~h}$ in rats and $3 \mathrm{~h}$ in healthy humans. Absolute oral bioavailability is $74 \%$. It distributes well across the various organs with limited penetration to the central nervous system. Moderate to high absorption and a relatively short half-life make Tofa a convenient model compound to study intestinal distribution. ${ }^{17,19-23}$

This study describes Tofa distribution in the distal GI tract at $1 \mathrm{~h}$ post dose, at the systemic $T_{\max }$ and at $7 \mathrm{~h}$ post dose, around the colon lumen $T_{\max }$ (the time when the unabsorbed fraction of the dose reaches the colon). Quantification was performed by combining the use of the isotope-labeled standard and spraying a dilution series over entire tissue sections per concentration to obtain tissue type-specific calibration curves. In this manner, quantitative information of the localization of Tofa in the ileum and proximal and distal colon at 1 and $7 \mathrm{~h}$ after dosing was obtained to provide the distinction between the lumen, mucosa, and muscle that cannot be obtained by regular LC-MS.

\section{METHODS}

Chemicals. 2,5-Dihydroxybenzoic acid (DHB) was purchased from Sigma-Aldrich (Zwijndrecht, The Netherlands). Tofacitinib (Tofa, CP-690550, Tasocitinib) was purchased from Selleckchem (Houston, TX) via distribution by VWR International LLC (Radnor, PA). Isotope-labeled Tofa $\left(\mathrm{C}_{13}{ }^{13} \mathrm{C}_{3} \mathrm{H}_{20} \mathrm{~N}_{5}{ }^{15} \mathrm{NO}\right)$ was purchased from Toronto Research Chemicals (Toronto, Canada). Water, methanol, ethanol, and heptane were obtained from Biosolve BV (Valkenswaard, The Netherlands); all solvents used were of high-performance liquid chromatography (HPLC) grade or better.

Animal Study. All animal procedures were conducted at the "Association for Assessment and Accreditation of Laboratory Animal Care International” accredited facility under an Institutional Animal Care and Use Committee approved protocol, which included the procedures for animal care, feeding, housing, and monitoring of environmental conditions. Eight weeks old male Sprague Dawley rats were purchased from Charles River Laboratories (Hollister, CA). The animals were fasted overnight prior to drug dosing. Tofa was prepared in a vehicle consisting of $20 \% 2$-hydroxypropyl- $\beta$ cyclodextrin. Animals received either the vehicle $(n=1$ per time point) or Tofa at $50 \mathrm{mg} / \mathrm{kg}(n=2$ per time point) as a single dose via oral gavage. This dose was based on earlier experiments where a $25 \mathrm{mg} / \mathrm{kg}$ dose was used in a rat study, resulting in low $\mu \mathrm{g} / \mathrm{g}$ levels of Tofa in the tissue homogenates (data not shown). Animals were sacrificed at 1 or $7 \mathrm{~h}$ post dose. For MSI, approximately $1 \mathrm{~cm}$ ileum, proximal colon, and distal colon were collected from each animal; feces was gently pushed out using cotton tips and tissues were flushed with 5 $\mathrm{mL}$ of saline. For quantitation of Tofa in the luminal content by LC-MS, a saline flush of $3 \mathrm{~mL}$ was collected from a $4 \mathrm{~cm}$ piece of the ileum. Both the flushing liquid and representative plasma samples were measured by a "standard" LC-MS/MS method deploying UPLC-QqQ system (Shimadzu LC30-Sciex API-4000) and a general aqueous to acetonitrile (both $0.1 \%$ formic acid) gradient within $2 \mathrm{~min}$ on a $2.1 \times 50 \mathrm{~mm}(2.5 \mu \mathrm{m})$ X-select T3 (Waters Corp.) column, respectively.

Sample Preparation. Tissues were mounted in a cryomicrotome using water. Tissue cross sections of $12 \mu \mathrm{m}$ thickness were cut and thaw mounted onto polylysineprecoated indium tin oxide-coated glass slides (Delta Technologies, Loveland, CO) and stored at $-80{ }^{\circ} \mathrm{C}$ until further handling. The isotope-labeled standard was dissolved in $70 \% \mathrm{MeOH}(5 \mu \mathrm{g} / \mathrm{g}$ tissue $)$ and sprayed onto the sample using a TM-sprayer (HTX-Technologies, Chapel Hill, NC), spraying 13 passes with a flow rate of $0.12 \mathrm{~mL} / \mathrm{min}$, a velocity of 1200 $\mathrm{mm} / \mathrm{min}$, and a track spacing of $2 \mathrm{~mm}$ at a temperature of 30 ${ }^{\circ} \mathrm{C}$ to obtain a final concentration of $3.02 \mathrm{ng} / \mathrm{mm}^{2}$. After having confirmed that Tofa was not removed by washing the tissue with heptane (see Supporting Figure 1), sections were washed with heptane for $3 \mathrm{~min}$ prior to MALDI matrix deposition. DHB dissolved in $70 \% \mathrm{MeOH}$ at a concentration of $40 \mathrm{mg} / \mathrm{mL}$ was sprayed over the tissue with the TM-sprayer, spraying six layers with a flow rate of $0.11 \mathrm{mg} / \mathrm{mL}$, a velocity of $1200 \mathrm{~mm} / \mathrm{min}$, and a track spacing of $2 \mathrm{~mm}$ at a temperature of $30{ }^{\circ} \mathrm{C}$.

A dilution series of the nonlabeled Tofa (dissolved in $70 \%$ $\mathrm{MeOH}$ ) was sprayed over the nondosed tissues with 

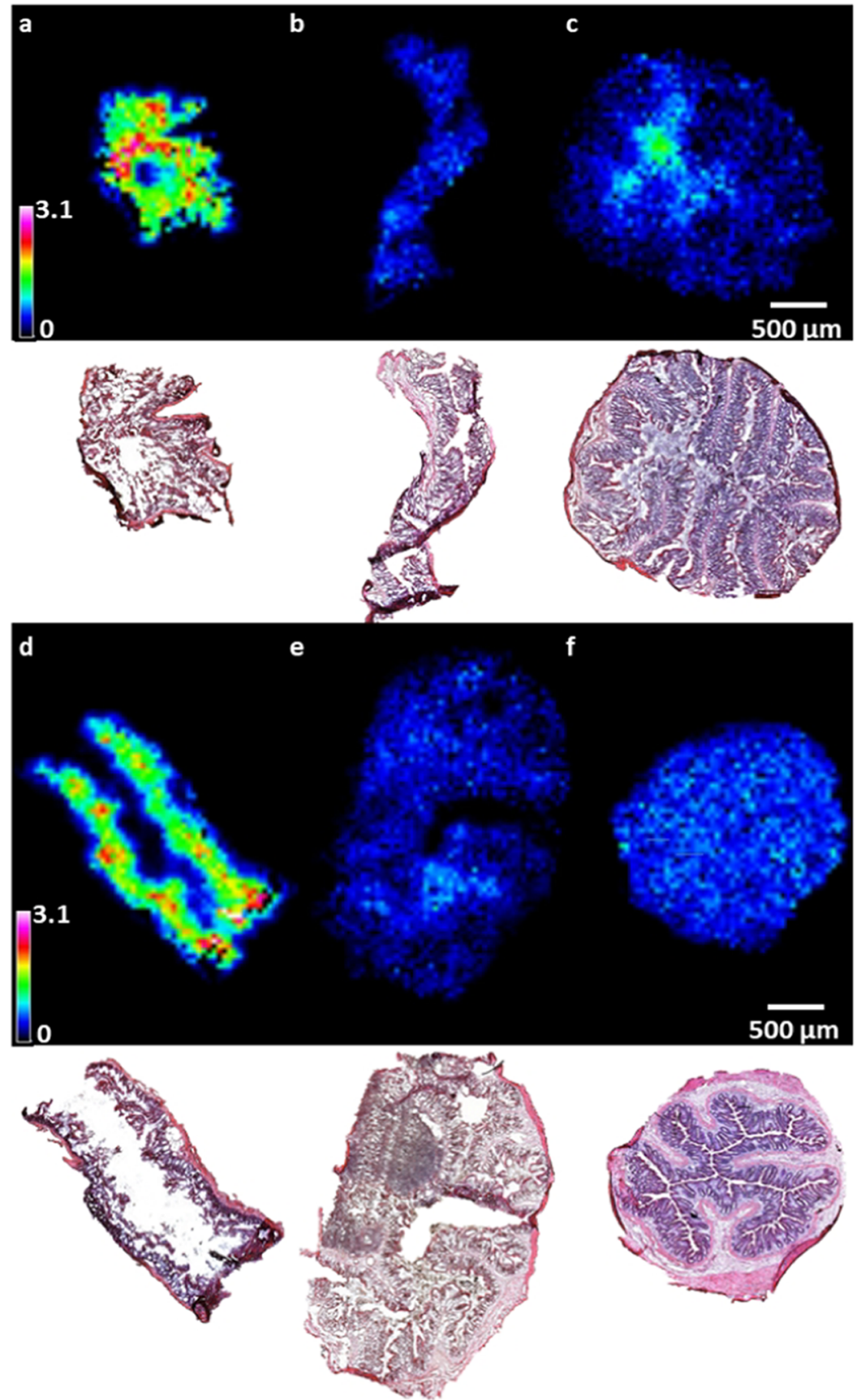

Figure 1. Distribution of Tofa $1 \mathrm{~h}$ post dose in animals $1(\mathrm{a}-\mathrm{c})$ and $2(\mathrm{~d}-\mathrm{f})$. Showing distribution in the ileum $(\mathrm{a}, \mathrm{d})$, proximal colon $(\mathrm{b}, \mathrm{e})$, and distal colon (c, f), with corresponding H\&E stains beneath ion distribution images. The signal is normalized to the signal of the isotope-labeled standard.

concentrations of $0.0,1.0,2.5,5.0,10.0,25.0,50.0,100.0$, and $250.0 \mu \mathrm{g} / \mathrm{g}$ of tissue using the TM-sprayer. Each concentration was sprayed over an entire tissue section and individual dilution series were made for the ileum, proximal colon, and distal colon. In addition, to validate the results from the dilution series, a control set of tissues was sprayed with concentrations of $10.0,50.0$, and $150.0 \mu \mathrm{g} / \mathrm{g}$ tissue. Similar to the dosed tissues, the isotope-labeled standard (IS) was sprayed over the tissues prior to washing the tissues and coating them with the matrix. The use of a $70 \% \mathrm{MeOH}$ solution for the individual solutions provided a "dry" spray, and delocalization of either the drug or the IS was not noted. Dilution and validation series were measured in triplicate. To attribute for the absence of tissues in the lumen, concentrations were also determined as pg/pixel.

MALDI-MSI Measurements. MALDI-MSI experiments were performed on a 9.4T Solarix Fourier transform ion cyclotron resonance mass spectrometer (Bruker Daltonik $\mathrm{GmbH}$, Bremen, Germany). Identification of Tofa and IS was based on the accurate mass measurement of the $[\mathrm{M}+\mathrm{H}]^{+}$ ion (a resolution of around 150.000) and confirmed by MS/ MS profiling. Two-hundred and twenty laser shots were accumulated at minimum laser focus with Smart Walk enabled at a width of $30 \mu \mathrm{m}$. A 4 Mword data point, $0.3670 \mathrm{~s}$ transient was acquired for each pixel and processed in a mass range from 200 to 900. Measurements were done in "Continuous 
Acquisition of Selected Ions" (CASI) mode with the quadrupole set at $313.2 \mathrm{~m} / z$ and an isolation window of 100 $m / z^{24}$ This setting allows for simultaneous detection of related metabolites. Reduced profile spectra were saved with a data reduction factor of $95 \%$. Imaging of the dosed tissues was performed at a pixel size of $50 \mu \mathrm{m}$, while imaging of the dilution series was performed at a pixel size of $75 \mu \mathrm{m}$ to reduce the measurement time. These measurements were performed with the same Smart Walk parameters, set to $30 \mu \mathrm{m}$, so that the same amount of material was "ablated" for good comparison.

Tissue Preparation for Histology. After MSI, the matrix was washed from the tissue section by submersion in methanol for $2 \mathrm{~min}$ and subsequent rehydration in water for $2 \mathrm{~min}$. Slides were stained with hematoxylin and eosin (H\&E) (Merck KGaA, Darmstadt, Germany) and mounted with Entellan. The H\&E slides were scanned using a Mirax Desk Scanner (Zeiss, Gottingen, Germany).

Analysis. H\&E images were imported into FlexImaging using the built-in overlay function. MSI ion images were exported as black and white Tagged Image File Format images. For quantitation, the images from the dilution series were loaded into ImageJ (Version 1.52a). Per tissue section, the intensity of Tofa (relative to the internal standard) was measured for three regions (the lumen, mucosa, and muscle layer) per intestinal section and three areas (similar in size and pathological homogeneity) were selected for each region on each tissue section based on the H\&E data excluding the regions where the tissue was folded. On average, $2-4 \%$ of the classified region per tissue type was selected for quantitation, resulting in $18-36 \%$ of the region (three tissue types in triplicate) per tissue slice being used for quantitation purposes. An intensity of 0 was considered as 'no signal' and an intensity of 255 was taken as the maximum signal. Intensity distributions were plotted as graphs using GraphPad Prism 5. Limit of detection (LOD) and limit of quantification (LOQ) were calculated as 3 and 10 times $\mathrm{S} / \mathrm{N}$, respectively, based on the signal observed from the tissues sprayed with $0 \mu \mathrm{g} / \mathrm{g}$ tissue of the internal standard in the dilution series. To determine the accuracy, the calculated values for the control sections were compared to the sprayed concentrations.

Three-dimensional (3D) mesh plots (@300 DPI) were made using the mesh function in MATLAB (version r2018a). The H\&E overlay was exported from FlexAnalysis with the exact same coordinates as the MSI ion image to provide an exact overlay between the intensities and the histology. A contour plot was plotted onto the $H \& E$ for further visualization using the contour function in MATLAB. In addition, the border between the lumen and the tissue was drawn onto the $\mathrm{H} \& \mathrm{E}$ images using an in-house written MATLAB script.

No unexpected, new, and/or significant hazards or risks associated with the described work and experiments have been observed

\section{RESULTS AND DISCUSSION}

Distribution of Tofa. Plasma concentrations of Tofa at 1 and $7 \mathrm{~h}$ post dose were relatively high and expected to produce comparable tissue exposures based on moderate plasma protein binding of $40 \%$ and a moderate volume of distribution of $87 \mathrm{~L}^{25}$ One of the aims of the experiment was to investigate whether the MSI technology is capable to distinguish between the drug absorbed into the colonic tissue from the lumen side and drug distribution from the blood. The analysis of intestinal washes suggests the high luminal concentration of Tofa at both 1 and $7 \mathrm{~h}$ (Supporting Table 1).

MSI experiments were performed on the tissue sections of the different parts of the intestine to investigate Tofa distribution across intestinal tissue layers. Remarkably, a strong Tofa signal was observed in the lumen of all sections (Figures 1-4) even though a thorough flushing procedure was undertaken, suggesting incomplete removal of the unabsorbed drug from the surface of the intestine.

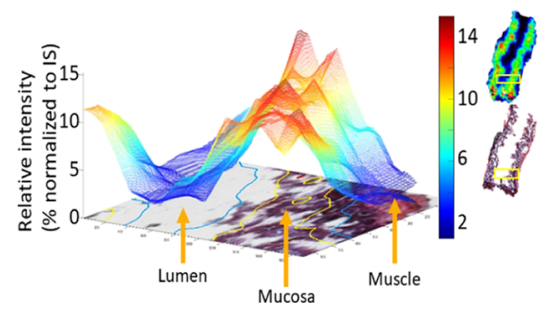

Figure 2. 3D intensity plot of Tofa of the selected region in the ileum $1 \mathrm{~h}$ post dose (animal 2). Intensity distribution relative to the internal standard plotted over the H\&E image of the corresponding section. Right-side images show the intensity distribution and the H\&E image of the entire section with the yellow box corresponding to the region used for 3D visualization. Colored lines show the contours of $5 \%$ (blue), 20\% (green), and 30\% (orange) relative intensity thresholds. Arrows point to muscle, mucosa, and lumen areas.

At $1 \mathrm{~h}$ post dose, the highest intensity of Tofa was observed in the ileum (Figure 1a,d). In the ileum, Tofa was highest in the region of the mucosa and only low levels were observed in the muscle layer. A significant signal was also observed in the lumen of the ileum (Figures 1 and 2). The Tofa signal in the proximal and distal colonic mucosa was much lower (Figure $1 b, c, e, f)$ than that in the ileum. Only a low signal was detected in the muscle layer, indicating that levels were close to the limit of detection. Most of the signals along the mucosa were located on the outer edge of the superficial mucosa, which could indicate that the majority of Tofa was adhering to the mucosa rather than being absorbed into the tissue.

The gradual decrease in the signal from the luminal side toward the bloodstream is indicative of a diffusion-based process, which suggests the passive absorption of Tofa rather than a specific transporter binding of Tofa, in which case, a sharp cutoff would have been anticipated (Figure 2 and Supporting Figures 2-4).

With a current imaging resolution of $50 \mu \mathrm{m}$, it is not possible to distinguish between the mucosa and the lumen area directly next to the mucosa. Unfortunately, improving the spatial resolution to $10-15 \mu \mathrm{m}$, required to distinguish between adsorption and absorption, led to a severe loss in sensitivity prohibiting the detection of Tofa in the tissue. Similar to the ileum, in the colon, some areas showed a high intensity of Tofa in the lumen, in particular in the distal colon of animal 3. The detection of Tofa in the colon lumen $1 \mathrm{~h}$ post dose surprised us at first, as this is faster than expected based on most reports on transit throughout the GI tract. ${ }^{26-30}$ Yet, several studies have shown that many factors can increase the passage rate through the GI tract including stress, drugs, and drug dosage. ${ }^{27,30-32}$

Therefore, it is possible that Tofa reaches the colon sooner than the standard formulations used for drug studies, especially since an effect of the high dose of Tofa on, e.g., gastric/ 

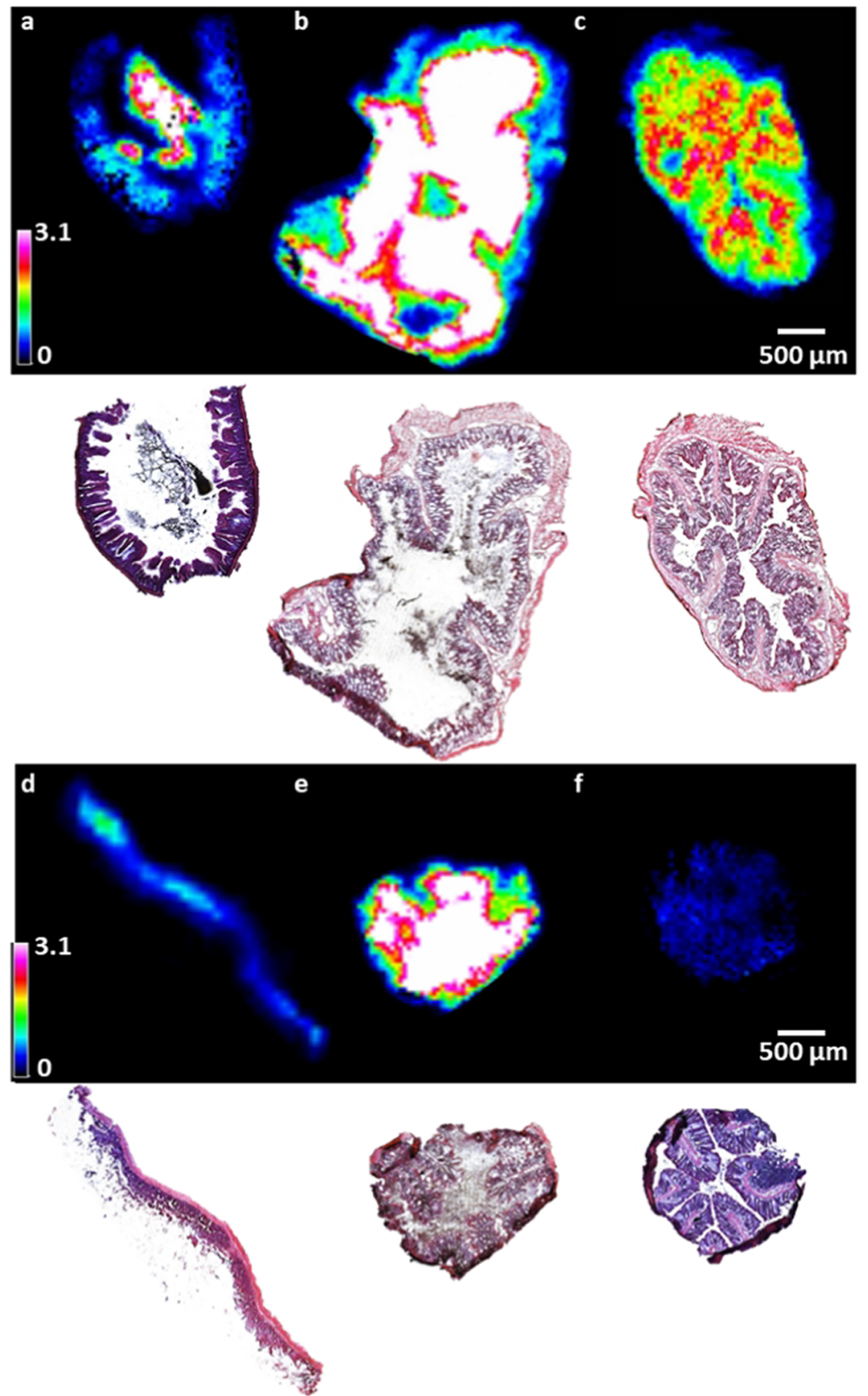

Figure 3. Distribution of Tofa $7 \mathrm{~h}$ post dose in animals $3(\mathrm{a}-\mathrm{c})$ and $4(\mathrm{~d}-\mathrm{f})$. Showing distribution in the ileum (a, d), proximal colon (b, e), and distal colon (c, f), with corresponding H\&E stains shown beneath ion distribution images. The signal is normalized to the signal of the isotopelabeled standard.

intestinal motility and gastric emptying cannot be excluded. Next, high concentration levels of Tofa in the lumen at $1 \mathrm{~h}$ could also be attributed to direct intestinal excretion. ${ }^{19,33}$

At $7 \mathrm{~h}$ post dose, intensities of more than $150 \%$ relative to the internal standard (IS) were observed in the lumen of the proximal colon, particularly in areas of the lumen where debris was still visible (Figures 3b,e and 4 and Supporting Figures 57). To enhance the contrast at the higher intensity, the intensity plot of the first isotope was also created (Supporting Figure 8). In addition, the on-tissue signal was mostly present at the mucosa rather than the submucosa, which suggests that Tofa is adsorbed rather than absorbed.
In the lumen of the ileum, similar high intensities for Tofa were observed in one sample (animal 3) in part of the lumen (Figure 3a), whereas in the other sample (animal 4), Tofa (Figure $3 \mathrm{~d}$ ) only displayed low signals up to $25 \%$ relative to the IS in the lumen. From the nonexisting ion distribution of Tofa $(m / z 313.1772)$ and the IS $(m / z 331.2065)$, on a blanc tissue slice (see Supporting Figure 9), the observed signal can indeed be attributed to Tofa, as background signals are negligible. Besides, it is clear that in these samples, severe ion suppression is observed, as IS signals outside the tissue region clearly "overshoot" those observed on the tissue.

However, due to the fragility of the frozen sample, these sections from the $7 \mathrm{~h}$ post dose-sacrificed animals were torn 


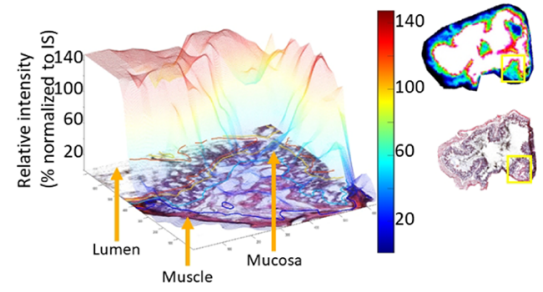

Figure 4. 3D intensity plot of Tofa of the selected region in the proximal colon $7 \mathrm{~h}$ post dose (animal 3). Intensity distribution relative to the internal standard plotted over the H\&E image of the corresponding section. Right-side images show the intensity distribution and the H\&E image of the entire section with the yellow box corresponding to the region used for $3 \mathrm{D}$ visualization. Colored lines show the contours of $10 \%$ (dark blue), $50 \%$ (light blue), and $120 \%$ (orange) relative intensity thresholds. Arrows point to the muscle layer, mucosa, and lumen areas.

open in the cutting process, so it is possible that the content of the lumen was not imaged in this case (Figure 3d). Likewise, the luminal content collected from the ileum of this animal was also 3-fold higher compared to the ileum from the other animal at this time point. Therefore, it is possible that in the sample with the high intensity, the flushing was not sufficient to remove all of the Tofa from the lumen, whereas in the lower intensity sample, flushing was more effective. In the distal colon, the Tofa signal was lower compared to that in the proximal colon and the ileum of the corresponding animal (Figure 3). Although lower compared to the other areas of the intestine, there was still a clear presence of Tofa in the lumen of the distal colon. Similar to the other samples, the signal along the mucosa was highest along the superficial mucosa and lower deeper in the tissue (submucosa). The high signal in the lumen corresponds to the expected lumen $T_{\max }$ at $7 \mathrm{~h}$.

Although the level of Tofa observed in the lumen is probably exaggerated by the high dose administered (see Methods section), it indicates that flushing of the intestines was not sufficient to fully clear the luminal content from the tissue surface. This will result in an overestimation of the tissue concentration when homogenized intestines are used for analysis by LC-MS/MS. This finding is especially important when drug tissue level quantitation is attempted during developing locally acting gut therapeutics.

Quantitation. Based on the dilution series sprayed over the tissue sections, the LOD of Tofa was estimated to be $5 \mu \mathrm{g} / \mathrm{g}$ tissue $(2.84 \mathrm{pg} / \mathrm{pixel}$ ) and an LOQ 15 of $\mu \mathrm{g} / \mathrm{g}$ tissue (9.45 pg/ pixel), resulting in a quantitative range between 15 and 250 $\mu \mathrm{g} / \mathrm{g}$ tissue. A calibration curve was made separately for the mucosa, muscle layer, and lumen regions from the ileum, proximal colon, and distal colon (Figure 5, Table 1, and Supporting Figure 10).
The distal colon provided the best calibration curves with $R^{2}$ values above 0.9 , with accuracies over $90 \%$ and overall good reproducibility. In contrast, the fit of the calibration curves was a lot lower for the ileum, especially in the lumen with a higher variation. The proximal colon showed a good fit for the mucosa and lumen and a variation of less than $20 \%$, but for the muscle layer, it showed an $R^{2}$ value of 0.89 with a variation at the highest concentration of approximately $30 \%$ (Figure 5 and Table 1). The higher variation for the lumen might be related to the fact that no/hardly any tissue is present in these luminal areas.

The higher quality calibration curves of the distal colon compared to those of the proximal colon and the ileum are attributed to the better-retained tissue morphology of the distal colon sections compared to the other two sections of the intestinal tract (Supporting Figure 11). Nonetheless, the calibration curves of all nine groups provided a good basis for the relative quantification of Tofa in the different tissue types of the intestinal tract.

Quantitation of the data confirms the observations that local Tofa levels in the lumen at $7 \mathrm{~h}$ post dose, especially of the proximal colon, are higher than expected and exceed the linear range of the dilution series (Table 2 and Supporting Table 2).

In addition, the average level of Tofa in the mucosa of the proximal colon exceeds this range as well. Given that the highest signal was observed at the superficial mucosa, this high intensity can be caused by the presence of Tofa on the luminal border, e.g., within mucus layer, rather than having been incorporated into the tissue. Although conventional LC-MS would have detected a high amount of Tofa in each intestinal segment, it would not have attributed this high level to the high amount of Tofa remaining in the lumen. This could have led to the conclusion that high amounts of Tofa were present in the tissue. In contrast, the quantitative MSI approach used here was able to confirm that the high signal of Tofa observed was indeed due to a high concentration of Tofa remaining in the lumen and did not simply owe to the reduced ion suppression in the lumen compared to the tissue. This could indicate that a depot of Tofa is formed in the intestine, explaining a higher than expected concentration of Tofa in the intestinal tissue relative to plasma at the later time point. ${ }^{34}$

\section{CONCLUSIONS}

The spatial component offered by MSI provided the possibility to demonstrate that a large proportion of Tofa remained in the lumen despite flushing of the intestines prior to freezing. Even though the larger measurement area was required for the detection of Tofa prevented distinction between the Tofa adsorbed to the surface of the villi and the Tofa absorbed into the tissue, MSI data was able to show that Tofa intensity

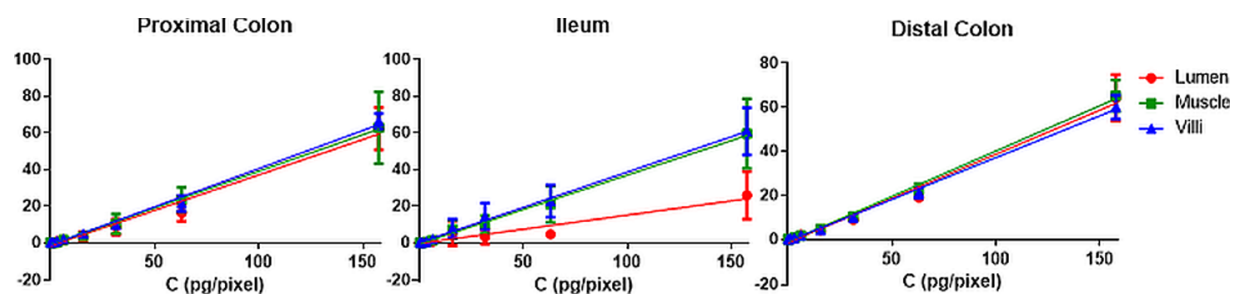

Figure 5. Calibration curves of Tofa. Calibration curves showing the intensity (normalized to IS) of Tofa in the ileum (a), proximal colon (b), and distal colon (c). Measurements were done individually for the mucosa (blue), muscle layer (green), and lumen (red). Measurements were done in triplicate with error bars (standard deviation). 
Table 1. Calibration Curve Characteristics Measured by MALDI-MSI

\begin{tabular}{|c|c|c|c|c|c|c|c|}
\hline \multirow[b]{3}{*}{ tissue type } & \multirow[b]{3}{*}{ area } & \multirow[b]{3}{*}{ equation } & \multirow[b]{3}{*}{$R^{2}$} & \multirow[b]{3}{*}{ accuracy (\%) } & \multicolumn{3}{|c|}{ RSD (\%) } \\
\hline & & & & & 150 & 75 & 10 \\
\hline & & & & & & $\overline{(\mu \mathrm{g} / \mathrm{g} \text { tissue })}$ & \\
\hline \multirow[t]{3}{*}{ ileum } & muscle & $y=0.23 x-0.54$ & 0.87 & 92 & 25 & 35 & 40 \\
\hline & mucosa & $y=0.21 x+0.39$ & 0.91 & 98 & 10 & 20 & 35 \\
\hline & lumen & $y=0.05 x-0.57$ & 0.67 & 94 & 20 & 25 & 25 \\
\hline \multirow[t]{3}{*}{ proximal colon } & muscle & $y=0.25 x-1.7$ & 0.89 & 94 & 30 & 25 & 15 \\
\hline & mucosa & $y=0.25 x-1.6$ & 0.98 & 95 & 5 & 10 & 15 \\
\hline & lumen & $y=0.19 x-0.19$ & 0.93 & 99 & 20 & 10 & 15 \\
\hline \multirow[t]{3}{*}{ distal colon } & muscle & $y=0.23 x-1.1$ & 0.98 & 91 & 5 & 20 & 15 \\
\hline & mucosa & $y=0.25 x-1.2$ & 0.99 & 93 & 5 & 35 & 10 \\
\hline & lumen & $y=0.271 x-1.8$ & 0.96 & 91 & 10 & 15 & 15 \\
\hline
\end{tabular}

Table 2. Average Concentration of Tofa $(\mu \mathrm{g} / \mathrm{g} \text { tissue })^{a}$

\begin{tabular}{|c|c|c|c|}
\hline & muscle & mucosa & lumen \\
\hline \multicolumn{4}{|l|}{$\begin{array}{l}1 \mathrm{~h} \text { post dose } \\
\text { ileum }\end{array}$} \\
\hline animal 1 & $32(18)$ & $75(30)$ & $32(16)^{*}$ \\
\hline animal 2 & $22(12)$ & $73(18)$ & $23(11)^{*}$ \\
\hline \multicolumn{4}{|l|}{ proximal colon } \\
\hline animal 1 & $<15$ & $28(5)$ & $23(4) *$ \\
\hline animal 2 & $<15$ & $21(6)$ & $10(5)^{*}$ \\
\hline \multicolumn{4}{|l|}{ distal colon } \\
\hline animal 1 & $<15$ & $27(11)$ & $27(4) *$ \\
\hline animal 2 & $<15$ & $36(4)$ & $19(2)$ \\
\hline \multicolumn{4}{|l|}{$\begin{array}{l}7 \mathrm{~h} \text { post dose } \\
\text { ileum }\end{array}$} \\
\hline animal 3 & $19(11)$ & $55(34)$ & $>140 *$ \\
\hline animal 4 & $29(11)$ & $67(26)$ & $19(12)^{*}$ \\
\hline \multicolumn{4}{|l|}{ proximal colon } \\
\hline animal 3 & $74(39)$ & $>250$ & $>140^{*}$ \\
\hline animal 4 & $65(49)$ & $>250$ & $>140^{*}$ \\
\hline \multicolumn{4}{|l|}{ distal colon } \\
\hline animal 3 & $57(26)$ & $214(35)$ & $115(18)^{*}$ \\
\hline animal 4 & $18(8)$ & $17(4)$ & $20(5)^{*}$ \\
\hline
\end{tabular}

${ }^{a}$ Two replicates, five regions per tissue type, numbers in brackets show standard deviation, measured by MALDI-MSI. The asterisk represents values for the lumen shown in $\mathrm{pg} /$ pixel.

gradually decreased from the lumen into the tissue corresponding to diffusion-like behavior. Therefore, passive absorption but predominantly adsorption to the intestinal surface takes place here. Our quantitative MALDI-MSI approach confirmed the presence of a high amount of Tofa remaining in the lumen, thereby giving credit to the theory that a depot of Tofa was present in the intestine, which would have led to overestimated tissue concentrations by conventional LC-MS/MS quantification in tissue homogenates. The ability of MSI to directly and quantitatively measure the luminal content versus the tissue content makes it a useful tool to study the passage of drugs across the intestinal wall.

\section{ASSOCIATED CONTENT}

\section{SI Supporting Information}

The Supporting Information is available free of charge at https://pubs.acs.org/doi/10.1021/acs.analchem.0c03956.

(3D) intensity plots; distribution of the $\mathrm{M}+1$ isotope; distribution of Tofa and sprayed IS on un-dosed tissue slice; individual calibration curves; representative $\mathrm{H} \& \mathrm{E}$ stain of sections used for quantification; Tofa concen- tration in the plasma and luminal wash solution measured by LC-MS; and average concentration of Tofa in pg/pixel (PDF)

\section{AUTHOR INFORMATION}

\section{Corresponding Author}

Rob J. Vreeken - Maastricht MultiModal Molecular Imaging Institute, Maastricht University, 6229 ER Maastricht, The Netherlands; Janssen Research \& Development, 2340 Beerse, Belgium; (1) orcid.org/0000-0003-3568-1371;

Email: rvreeken@maastrichtuniversity.nl

\section{Authors}

Lennart R. S. Huizing - Maastricht MultiModal Molecular Imaging Institute, Maastricht University, 6229 ER Maastricht, The Netherlands

James McDuffie - Janssen Research \& Development, San Diego, California 92121, United States

Filip Cuyckens - Janssen Research \& Development, 2340 Beerse, Belgium; (1) orcid.org/0000-0003-4956-1418

Marjolein van Heerden - Janssen Research \& Development, 2340 Beerse, Belgium

Tatiana Koudriakova - Janssen Research \& Development, San Diego, California 92121, United States

Ron M. A. Heeren - Maastricht MultiModal Molecular Imaging Institute, Maastricht University, 6229 ER Maastricht, The Netherlands; (1) orcid.org/0000-00026533-7179

Complete contact information is available at:

https://pubs.acs.org/10.1021/acs.analchem.0c03956

\section{Author Contributions}

The manuscript was written through contributions of all authors. All authors have given approval to the final version of the manuscript.

Notes

The authors declare no competing financial interest.

\section{ACKNOWLEDGMENTS}

This research was part of the M4I research program and received financial support from the Dutch Province of Limburg under the LINK program and the Integrated Technology Strategy (ITS) initiative program of Janssen Pharmaceutica NV. The authors thank Bryn Flinders (DSG, Maastricht, the Netherlands) and Avijt Ghosh (Janssen R\&D, Springhouse, USA) for their in-depth discussion. 


\section{REFERENCES}

(1) Nilsson, A.; Peric, A.; Strimfors, M.; Goodwin, R. J. A.; Hayes, M. A.; Andrén, P. E.; Hilgendorf, C. Sci. Rep. 2017, 7, No. 6352.

(2) Masaoka, Y.; Tanaka, Y.; Kataoka, M.; Sakuma, S.; Yamashita, S. Eur. J. Pharm. Sci. 2006, 29, 240-250.

(3) Amidon, S.; Brown, J. E.; Dave, V. S. AAPS PharmSciTech 2015, 16, 731-741.

(4) Banerjee, A.; Pathak, S.; Subramanium, V. D.; Dharanivasan, G.; Murugesan, R.; Verma, R. S. Drug Discovery Today 2017, 22, 12241232 .

(5) Belali, N.; Wathoni, N.; Muchtaridi, M. J. Adv. Pharm. Technol. Res. 2019, 10, 100-106.

(6) Römpp, A.; Guenther, S.; Takats, Z.; Spengler, B. Anal. Bioanal. Chem. 2011, 401, 65-73.

(7) Barry, J. A.; Ait-Belkacem, R.; Hardesty, W. M.; Benakli, L.; Andonian, C.; Licea-Perez, H.; Stauber, J.; Castellino, S. Anal. Chem. 2019, 91, 6266-6274.

(8) Sørensen, I. S.; Janfelt, C.; Nielsen, M. M. B.; Mortensen, R. W.; Knudsen, N. Ø.; Eriksson, A. H.; Pedersen, A. J.; Nielsen, K. T. Anal. Bioanal. Chem. 2017, 409, 4933-5005.

(9) Prideaux, B.; Lenaerts, A.; Dartois, V. Curr. Opin. Chem. Biol. 2018, 44, 93-100.

(10) Nilsson, A.; Goodwin, R. J. A.; Shariatgorji, M.; Vallianatou, T.; Webborn, P. J. H.; Andrén, P. E. Anal. Chem. 2015, 87, 1437-1455.

(11) Vaysse, P.-M.; Heeren, R. M. A.; Porta, T.; Balluff, B. Analyst 2017, 142, 2690-2712.

(12) Lietz, C. B.; Gemperline, E.; Li, L. Adv. Drug Delivery Rev. 2013, $65,1074-1085$.

(13) Ou, Y.-M.; Tsao, C.-W.; Lai, Y.-H.; Lee, H.; Chang, H.-T.; Wang, Y.-S. J. Vis. Exp. 2016, 116, No. 54409.

(14) Hamm, G.; Bonnel, D.; Legouffe, R.; Pamelard, F.; Delbos, J. M.; Bouzom, F.; Stauber, J. J. Proteomics 2012, 75, 4952-4961.

(15) Hu, J. B.; Chen, Y. C.; Urban, P. L. Anal. Chim. Acta 2013, 766, $77-82$.

(16) Bannwarth, B.; Kostine, M.; Poursac, N. Exp. Opin. Drug Metab. Toxicol. 2013, 9, 753-761.

(17) Flanagan, M. E.; Blumenkopf, T. A.; Brissette, W. H.; Brown, M. F.; Casavant, J. M.; Shang-Poa, C.; Doty, J. L.; Elliott, E. A.; Fisher, M. B.; Hines, M.; Kent, C.; Kudlacz, E. M.; Lillie, B. M.; Magnuson, K. S.; McCurdy, S. P.; Munchhof, M. J.; Perry, B. D.; Sawyer, P. S.; Strelevitz, T. J.; Subramanyam, C.; Sun, J.; Whipple, D. A.; Changelian, P. S. J. Med. Chem. 2010, 53, 8468-8484.

(18) Danese, S.; Grisham, M.; Hodge, J.; Telliez, J. B. Am. J. Physiol. 2016, 310, G155-G162.

(19) Xeljanz EPAR Medicine Overview. 2018. https://www.ema. europa.eu/en/medicines/human/EPAR/xeljanz.

(20) Bannwarth, B.; Kostine, M.; Poursac, N. Exp. Opin. Drug Metab. Toxicol. 2013, 9, 753-761.

(21) O’Brien, Z.; Moghaddam, M. F. Curr. Med. Chem. 2017, 24, $3159-3184$

(22) Sharma, K.; Giri, K.; Dhiman, V.; Dixit, A.; Zainuddin, M.; Mullangi, R. Biomed. Chromatogr. 2015, 29, 722-732.

(23) Bharwad, K. D.; Shah, P. A.; Shrivastav, P. S.; Singhal, P. Biomed. Chromatogr. 2019, 33, No. e4458.

(24) Witt, M. Application Note \# FTMS-46 Solarix XR: Analysis of Complex Mixtures. 2012. https://www.bruker.com/fileadmin/user upload/8-PDF-Docs/Separations_MassSpectrometry/Literature/ literature/ApplicationNotes/FTMS-46 solarix XR 2012 eBook.pdf.

(25) Cada, D. J.; Demaris, K.; Levien, T. L.; Baker, D. E. Hosp. Pharm. 2013, 48, 413-424.

(26) Miller, M. S.; Galligan, J. J.; Burks, T. F. J. Pharmacol. Methods 1981, 6, 211-217.

(27) Dalziel, J. E.; Young, W.; McKenzie, C. M.; Haggarty, N. W.; Roy, N. C. Nutrients 2017, 9, No. 1351.

(28) Miller, M. S.; Galligan, J. J.; Burks, T. F. J. Pharmacol. Methods 1981, 6, 211-217.

(29) Haruta, S.; Kawai, K.; Jinnouchi, S.; Ogawara, K. I.; Higaki, K.; Tamura, S.; Arimori, K.; Kimura, T. J. Pharm. Sci. 2001, 90, 464-473.

(30) Kimura, T.; Higaki, K. Biol. Pharm. Bull. 2002, 25, 149-164.
(31) Dalziel, J. E.; Young, W.; Bercik, P.; Spencer, N. J.; Ryan, L. J.; Dunstan, K. E.; Lloyd-West, C. M.; Gopal, P. K.; Haggarty, N. W.; Roy, N. C. Neurogastroenterol. Motil. 2016, 28, 1241-1251.

(32) Munakata, A.; Iwane, S.; Todate, M.; Nakaji, S.; Sugawara, K. Tohoku J. Exp. Med. 1995, 176, 227-238.

(33) Lee, J. S.; Kim, S. H. Pharmaceutics 2019, 11, No. 318.

(34) Lamba, M.; Wang, R.; Fletcher, T.; Alvey, C.; Kushner, J., IV; Stock, T. C. J. Clin. Pharmacol. 2016, 56, 1362-1371. 